\title{
Pengaruh Suplementasi Seng dan Vitamin A Terhadap Kejadian ISPA dan Diare pada Anak
}

\author{
Fita Asfianti, H.M.Nazir, Syarif Husin, Theodorus \\ Departemen Ilmu Kesehatan Anak Rumah Sakit Moh.Hoesin /Fakultas Kedokteran Universitas Sriwijaya, \\ Palembang
}

\begin{abstract}
Latar belakang. Salah satu faktor yang memengaruhi tingginya angka kejadian infeksi saluran pernapasan akut (ISPA) dan diare adalah defisiensi vitamin A. Walaupun di Indonesia telah didapat program pemberian vitamin A, tetapi masih banyak anak dengan defisiensi vitamin A karena defisiensi seng. Suplementasi seng dan vitamin A diharapkan dapat meningkatkan kadar seng dan vitamin A pada anak sehingga dapat menurunkan angka kejadian ISPA dan diare.

Tujuan. Mengetahui pengaruh suplementasi seng dan vitamin A terhadap kejadian ISPA dan diare.

Metode. Penelitian kohort dilakukan selama bulan Agustus 2009-Februari 2010. Sampel anak usia 12-60 bulan diambil dari 5 Posyandu di Puskesmas Talang Ratu, Palembang. Pemeriksaan kadar seng dan vitamin A dilakukan dua kali, yaitu sebelum dan sesudah suplementasi seng (200 mg per hari selama dua minggu) dan vitamin A (200 000 IU). Pemeriksaan kadar seng menggunakan Atomic Absorbtion Spectroscope (AAS), dan kadar vitamin A dengan spektrofotometer. Uji bivariat dan multivariat dianalisis dengan SPSS 15, dengan $\mathrm{p}<0,05$.

Hasil. Didapatkan 88 subjek penelitian, terdiri dari 45 (51,1\%) laki-laki dan 43 (48,9\%) perempuan.. Rerata umur 28,44 $\pm 12,34$ bulan. Terdapat perbedaan rerata kadar seng dan vitamin A pada anak sebelum dan setelah diberikan suplementasi seng dan vitamin A $60,61 \pm 31,36 \mu \mathrm{g} / \mathrm{dL}$ vs $84,76 \pm 22,87 \mu \mathrm{g} / \mathrm{dL}(\mathrm{p}<0,05)$, dan $19,73 \pm 5,96 \mu \mathrm{g} / \mathrm{dL}$ vs $23,54 \pm 5,88 \mu \mathrm{g} / \mathrm{dL}(\mathrm{p}<0,05)$. Angka kejadian ISPA setelah suplementasi menurun dari $61,4 \%$ menjadi $22,7 \%$, dan diare dari $28,4 \%$ menjadi 26,1\%. Kadar seng dan vitamin A berpengaruh terhadap kejadian ISPA dan diare $(\mathrm{p}<0,05)$.

Kesimpulan. Terdapat pengaruh suplementasi seng dan vitamin A terhadap penurunan angka kejadian ISPA dan diare. Sari Pediatri 2013;15(2):93-8.
\end{abstract}

Kata kunci: diare, ISPA, seng, vitamin A, suplementasi

Alamat korespondensi:

Dr. Fita Asfianti. Departemen Ilmu Kesehatan Anak FK Universitas Sriwijaya/ RS Mohammad Hoesin, Jl Jend Sudirman Km 3,5, Palembang, Sumatera Selatan, 30126. E-mail: fita_dr@yahoo.co.id
I nfeksi saluran pernapasan akut (ISPA) dan diare masih merupakan penyebab utama morbiditas di negara yang sedang berkembang, termasuk di Indonesia. ${ }^{1}$ Kadar zat gizi seperti vitamin A telah diketahui merupakan salah satu faktor yang berpengaruh pada tingkat kejadian ISPA dan diare. ${ }^{2} \mathrm{Di}$ 
Indonesia, terdapat program pemerintah berupa suplementasi vitamin A untuk mencegah dan mengatasi defisiensi vitamin A pada anak dengan harapan dapat mengurangi morbiditas berbagai penyakit, seperti ISPA dan diare. ${ }^{3}$ Program tersebut telah dilaksanakan sejak tahun 1976, tetapi masih ditemukan 50,2\% anak balita dengan kadar serum vitamin $A<20$ g/ dl. ${ }^{3}$ Rahman $\mathrm{dkk}^{4}$ melaporkan bahwa lebih dari $60 \%$ anak mengalami defisiensi vitamin A meskipun sudah mendapatkan suplementasi vitamin A dosis tinggi. Hal tersebut kemungkinan disebabkan karena adanya defisiensi seng. ${ }^{4}$

Defisiensi seng akan menyebabkan gangguan absorbsi, sintesis, dan transpor vitamin A, sehingga kadar vitamin A dalam sirkulasi juga rendah. Akibatnya, fungsi vitamin A terhadap imunitas juga berkurang dan memudahkan terjadinya infeksi, seperti ISPA dan diare. ${ }^{5}$ Long $\mathrm{dkk}^{6}$ melaporkan penurunan kejadian ISPA dan diare pada anak yang disuplementasi seng dan vitamin A. Fedriansyah ${ }^{7}$ melaporkan bahwa status seng dan vitamin A merupakan faktor yang memengaruhi secara bermakna terhadap kejadian ISPA dan diare. Namun, Chang $\mathrm{dkk}^{8}$ melaporkan bahwa pemberian suplementasi seng dan vitamin A tidak bermakna dalam menurunkan kejadian ISPA dan diare.

Penelitian mengenai pengaruh suplementasi seng dan vitamin A terhadap kejadian ISPA dan diare pada anak juga perlu dilakukan di Indonesia, khususnya di Palembang, mengingat masih banyak balita yang mengalami defisiensi vitamin A walaupun program pemberian vitamin A telah dilaksanakan sejak lama oleh pemerintah. Hal tersebut berakibat masih tingginya angka kejadian ISPA dan diare di Indonesia. Pemberian suplementasi seng dan vitamin A diharapkan dapat meningkatkan kadar seng dan vitamin A pada anak sehingga dapat menurunkan angka kejadian ISPA dan diare.

\section{Metode}

Penelitian ini merupakan penelitian kohort yang dilaksanakan dari bulan Agustus 2009 sampai Februari 2010 di Posyandu di wilayah kerja Puskesmas Talang Ratu, Palembang.

Populasi penelitian adalah semua anak usia 12-60 bulan yang tinggal di wilayah Puskesmas Talang Ratu, Palembang yang sesuai program pemerintah akan mendapat suplementasi vitamin A pada bulan Agustus
2009. Besar sampel dihitung dengan menggunakan tabel sample sizes for cohort studies. Dengan insiden $60 \%$, RR : $1,5, \alpha: 0,05, \beta: 0,10$, maka didapatkan 84 jumlah sampel. Untuk mengantisipasi drop out, jumlah sampel ditambahkan 20\%, sehingga total 100 sampel. Anak dengan infeksi berat pada waktu dilakukan pengambilan darah (meningitis, ensefalitis, DBD, dan lain-lain penyakit yang memerlukan perawatan di rumah sakit) dan anak dengan gizi buruk dieksklusi dari penelitian ini. Pada semua sampel penelitian dilakukan pemeriksaan fisik, meliputi berat badan, tinggi badan atau panjang badan, dan status gizi. Kemudian dilakukan pengukuran kadar seng dan vitamin A (retinol) serum. Defisiensi seng adalah jika kadar seng serum $<70 \mu \mathrm{g} / \mathrm{dL}$ (menurut United States Interdepartmental Committee on Nutrition for National Defence). Defisiensi vitamin A adalah jika kadar vitamin A serum $<20 \mu \mathrm{g} / \mathrm{dL}$ (menurut United States Interdepartmental Committee on Nutrition for National Defence).

Pengukuran kadar seng dan vitamin A plasma dilakukan dua kali, yaitu pertama sebelum anak mendapat suplementasi vitamin A dan seng pada bulan Agustus 2009 dan kedua pada bulan Februari 2010 (6 bulan setelah suplementasi seng dan vitamin A). Pemeriksaan kadar seng dengan menggunakan Atomic Absorbtion Spectroscope (AAS) (model 3110, Perkin-Elmer Corporation, Norwlk, CT). Pemeriksaan vitamin A dengan menggunakan spektrofotometer pada panjang gelombang $620 \mathrm{~nm}$. Suplementasi yang diberikan adalah suplementasi seng $1 \mathrm{x}$ $200 \mathrm{mg}$ selama dua minggu dan suplementasi vitamin A sesuai program pemerintah, yaitu vitamin A kapsul 200 000 IU untuk anak usia 12-60 bulan. Setiap orang tua dari subjek penelitian diberikan lembaran data untuk diisi ketika terjadi gejala-gejala ISPA dan diare pada anaknya. Data yang sudah diisi akan dikumpulkan oleh kader dan diganti dengan lembaran data yang kosong setiap dua minggu. Data dicatat pada formulir isian penelitian, kemudian dimasukkan ke dalam komputer dengan program SPSS 15. Data dasar umum dianalisis secara deskriptif dan ditampilkan dalam bentuk tabel distribusi dan frekuensi. Data katagori ditampilkan dalam bentuk tabel dan dianalisis dengan menggunakan chisquare untuk variabel diskret.

\section{Hasil}

Didapatkan 92 subjek penelitian yang memenuhi kriteria inklusi, 4 (4,3\%) subjek drop out, sehingga hanya 
88 orang yang diikutsertakan dalam penelitian ini. Rerata umur subjek $28,44 \pm 12,34$ bulan, atau $2,37 \pm 1,03$ tahun. Sebaran umur terbanyak pada kelompok umur 37-60 bulan 45(51,1\%) subjek. Karakteristik jenis kelamin terbanyak terdapat pada jenis kelamin laki-laki 45(51,1\%) subjek. Berdasarkan status gizi, 39 (44,3\%) subjek memiliki status gizi baik dan 49 (55,7\%) subjek gizi kurang. Subjek yang memiliki riwayat ASI eksklusif $69(78,4 \%)$ subjek dan riwayat imunisasi lengkap 67 $(76,1 \%)$ subjek. Karakteristik subjek penelitian secara lengkap tertera pada Tabel 1.

Rerata kadar seng subjek penelitian sebelum suplementasi $60,61 \pm 31,36 \mu \mathrm{g} / \mathrm{dL}$ dan mengalami kenaikan setelah suplementasi menjadi $84,76 \pm 22,87$

Tabel 1. Karakteristik subjek penelitian $(\mathrm{n}=88)$

\begin{tabular}{lcc}
\hline Karakteristik & Jumlah & Persentase \\
\hline Umur (bulan) & & \\
$\quad 12-36$ & 43 & 48,9 \\
$37-60$ & 45 & 51,1 \\
Jenis kelamin & & \\
$\quad$ Laki-laki & 45 & 51,1 \\
$\quad$ Perempuan & 43 & 48,9 \\
Status gizi & & \\
$\quad$ Baik & 39 & 44,3 \\
$\quad$ Kurang & 49 & 55,7 \\
Riwayat ASI & & \\
$\quad$ Eksklusif & 69 & 78,4 \\
$\quad$ Tidak eksklusif & 19 & 21,6 \\
Riwayat imunisasi & & \\
$\quad$ Lengkap & 67 & 76,1 \\
$\quad$ Tidak lengkap & 21 & 23,9 \\
\hline
\end{tabular}

Tabel 2. Rerata kadar seng dan vitamin a sebelum dan sesudah suplementasi seng dan vitamin A $(\mathrm{n}=88)$

\begin{tabular}{lcc}
\hline Parameter & Sebelum & Sesudah \\
\hline Seng & $60,61 \pm 31,36$ & $84,76 \pm 22,87$ \\
vitamin A & $19,73 \pm 5,96$ & $23,54 \pm 5,88$ \\
\hline
\end{tabular}

Uji t-berpasangan $\mu \mathrm{g} / \mathrm{dL}$. Analisis statistik uji t menunjukkan terdapat perbedaan bermakna rerata kadar seng sebelum dan sesudah suplementasi seng dan vitamin $A(p=0,001)$. Pada kadar vitamin A, rerata kadarnya sebelum suplementasi $19,73 \pm 5,96 \mu \mathrm{g} / \mathrm{dL}$ menjadi $23,54 \pm 5,88 \mu \mathrm{g} /$ dL setelah suplementasi. Terdapat perbedaan bermakna rerata kadar vitamin A sebelum dan sesudah suplementasi $(\mathrm{p}=0,001)$. Rerata kadar seng dan vitamin A pada subjek penelitian sebelum dan sesudah suplementasi secara lengkap tertera pada Tabel 2 .

Status kadar seng sebelum suplementasi seng dan vitamin A didapatkan 69,3\% subjek yang mengalami defisiensi seng. Setelah disuplementasi selama 6 bulan, subjek yang mengalami defisiensi seng menurun menjadi 14,8\%. Status kadar vitamin A sebelum suplementasi didapatkan $64,8 \%$ subjek yang mengalami defisiensi vitamin A. Setelah disuplementasi selama 6 bulan, subjek yang mengalami defisiensi vitamin A menurun menjadi $18,2 \%$. Status kadar seng dan vitamin A sebelum dan sesudah suplementasi secara lengkap tertera pada Tabel 3.

Angka kejadian ISPA sebelum suplementasi seng dan vitamin A didapatkan 61,4\%, dan setelah disuplementasi selama 6 bulan angka kejadian ISPA menurun menjadi $22,7 \%$. Sebelum suplementasi seng dan vitamin A didapatkan angka kejadian diare 28,4\%, dan setelah disuplementasi selama 6 bulan angka kejadian diare menurun menjadi 26,1\%. Angka kejadian ISPA dan diare sebelum dan sesudah suplementasi seng secara lengkap tertera pada Tabel 4.

Tigabelas subjek dengan defisiensi seng, 61,5\% di antaranya mengalami ISPA dan 38,5\% tidak ISPA. Terdapat 75 subjek dengan status seng normal, 16\% di antaranya mengalami ISPA dan $84 \%$ tidak ISPA. Secara statistik, terdapat hubungan yang bermakna antara status seng dengan kejadian ISPA setelah suplementasi seng dan vitamin A ( $\mathrm{p}=0,001$; RR 3,846; IK 95\%:1,961-7,543).

Subjek yang mengalami defisiensi seng dengan diare $53,8 \%$ dan $46,2 \%$ tidak diare. Sedangkan subjek penelitian dengan status kadar seng normal dengan di-

Tabel 3. Status seng dan vitamin A sebelum dan sesudah suplementasi seng dan vitamin A ( $\mathrm{n}=88)$

\begin{tabular}{lcccc}
\hline \multirow{2}{*}{ Suplementasi seng \& vitamin A } & \multicolumn{2}{c}{ Status seng } & \multicolumn{2}{c}{ Status vitamin A } \\
\cline { 2 - 5 } & $\begin{array}{c}\text { Defisiensi } \\
(<70 \mu \mathrm{g} / \mathrm{dL})\end{array}$ & $\begin{array}{c}\text { Normal } \\
(\geq 70 \mu \mathrm{g} / \mathrm{dL})\end{array}$ & $\begin{array}{c}\text { Defisiensi } \\
(<20 \mu \mathrm{g} / \mathrm{dL})\end{array}$ & $\begin{array}{c}\text { Normal } \\
(\geq 20 \mu \mathrm{g} / \mathrm{dL})\end{array}$ \\
\hline Sebelum & $61(69,3 \%)$ & $27(30,7 \%)$ & $57(64,8 \%)$ & $31(35,2 \%)$ \\
Sesudah & $13(14,8 \%)$ & $75(85,2 \%)$ & $16(18,2 \%)$ & $72(81,8 \%)$ \\
\hline
\end{tabular}


Fita Asfianti dkk: Pengaruh suplementasi seng dan vitamin A terhadap kejadian ISPA dan diare

Tabel 4. Angka kejadian ISPA dan diare sebelum dan sesudah suplementasi seng dan vitamin A ( $\mathrm{n}=88$ )

\begin{tabular}{lcccc}
\hline \multirow{2}{*}{ Suplementasi seng \& vitamin A } & \multicolumn{2}{c}{ Angka kejadian ISPA } & \multicolumn{2}{c}{ Angka kejadian diare } \\
\cline { 2 - 5 } & ISPA & $\%$ & Diare & $\%$ \\
\hline Sebelum & 54 & 61,4 & 25 & 28,4 \\
Sesudah & 20 & 22,7 & 23 & 26,1 \\
\hline
\end{tabular}

are $21,3 \%$, dan $78,7 \%$ tidak diare. Terdapat hubungan yang bermakna antara status kadar seng dengan kejadian diare setelah suplementasi ( $\mathrm{p}=0,014 ; \mathrm{RR} 2,524$; IK95\%:1,298-4,908).

Enambelas subjek dengan defisiensi vitamin A, $75 \%$ di antaranya mengalami ISPA dan $25 \%$ tidak ISPA. Terdapat 72 subjek dengan status kadar vitamin A normal, $11,1 \%$ di antaranya mengalami ISPA dan $88,9 \%$ tidak ISPA.

Berdasarkan analisis statistik uji Fisher, terdapat hubungan yang bermakna antara status kadar vitamin A dengan kejadian ISPA setelah suplementasi seng dan vitamin A ( $\mathrm{p}=0,001$; RR 6,750; IK 95\%:3,31213,756).

Subjek penelitian yang mengalami defisiensi vitamin A dengan diare 81,3\% dan 18,7 tidak diare. Sedangkan subjek penelitian dengan status kadar vitamin A normal dengan diare $13,9 \%$ dan $86,1 \%$ tidak diare. Terdapat hubungan yang bermakna antara status kadar vitamin A dengan kejadian diare setelah suplementasi ( $\mathrm{p}=0,001$; RR 5,850; IK 95\%:3,14210,890).

\section{Pembahasan}

Penelitian kami bertujuan untuk mengetahui pengaruh suplementasi seng dan vitamin A terhadap kejadian ISPA dan diare pada anak. Periode penelitian diikuti 88 subjek, rerata umur $28,44 \pm 12,34$ bulan, atau $2,37 \pm 1,03$ tahun. Karakteristik jenis kelamin terbanyak adalah laki-laki $(51,1 \%)$. Sebagian besar subjek memiliki status gizi kurang (55,7\%). Karakteristik subjek pada penelitian kami tidak jauh berbeda dengan penelitian yang dilakukan Sazawal $\mathrm{dkk}^{9}$ yang melaporkan rerata umur subjek $18,6 \pm 8,5$ bulan dengan proporsi status gizi kurang 52,6\%.

Seng berperan dalam metabolisme dan transpor vitamin A serta dibutuhkan pada sintesis protein transpor retinol (PTR), yaitu PTR hepatik seluler (cPTR) me- rupakan protein transpor intrasel retinol dalam sel-sel hepar, dan holoPTR yang membawa retinol dari hepar ke dalam darah dan jaringan sasaran lainnya. Selain itu, seng juga dibutuhkan pada proses oksidatif di jaringan perifer yang membutuhkan aktifasi zinc-dependent retinol dehydrogenase enzyme, antara lain alkohol dehidrogenase $(\mathrm{ADH})$, dan retinal oksidase. ${ }^{10}$

Banyak penelitan telah menunjukkan interaksi antara seng dan vitamin A. Penelitian pada hewan percobaan menunjukkan bahwa defisiensi seng akan menyebabkan penurunan konsentrasi RBP dalam plasma, dan suplementasi vitamin A pada hewan percobaan tersebut gagal memperbaiki defisisensi vitamin A. Setelah hewan percobaan diberikan suplementasi seng, konsentrasi retinol plasma meningkat. ${ }^{11-13} \mathrm{Hal}$ tersebut menunjukkan bahwa kadar retinol yang rendah berhubungan dengan defisiensi seng.

Kadar seng dan vitamin A dapat memengaruhi kejadian ISPA pada anak. Angka kejadian ISPA yang mendapat vitamin A saja sesuai dengan program pemerintah didapatkan 62\% (Fedriansyah, 2010). ${ }^{7}$ Pada penelitian kami, angka kejadian ISPA setelah disuplementasi selama 6 bulan menurun menjadi 22,7\%. Terdapat hubungan yang bermakna antara kejadian ISPA pada anak yang tidak mengalami defisiensi seng dan vitamin A dan pada anak dengan defisiensi seng dan vitamin A setelah suplementasi seng dan vitamin $A(p=0,001)$. Hasil penelitian kami tidak jauh berbeda dengan penelitian sebelumnya yang dilakukan oleh Long $\mathrm{dkk}^{6}$ yang menyatakan bahwa terjadi penurunan kejadian ISPA dan diare pada anak yang disuplementasi seng dan vitamin A. Menurut Bhandari dkk, ${ }^{14}$ pemberian suplementasi seng pada anak prasekolah di Dakshinpuri New Delhi dapat mengurangi kejadian pneumonia dan ISPA.

Angka kejadian diare pada anak yang mendapat vitamin A saja sesuai dengan program pemerintah didapatkan 30,4\% (Fedriansyah, 2010). . Pada penelitian kami, angka kejadian diare setelah disuplementasi selama 6 bulan menurun menjadi $26,1 \%$. Terdapat 
Fita Asfianti dkk: Pengaruh suplementasi seng dan vitamin A terhadap kejadian ISPA dan diare

hubungan yang bermakna antara kejadian diare pada anak yang tidak mengalami defisiensi seng dan vitamin A dan pada anak yang mengalami defisiensi seng dan vitamin A setelah suplementasi seng dan vitamin A $(\mathrm{p}=0,001)$.

Hasil penelitian kami mendukung penelitian sebelumnya yang dilakukan Sempertequi $\mathrm{dkk}^{15}$, dan Ruel $\mathrm{dkk}^{16}$ yang mendapatkan terjadi penurunan insiden diare pada anak yang mendapat suplementasi seng. Aggarwal ${ }^{17}$ yang melaporkan terjadi penurunan frekuensi dan lama serangan diare pada anak yang mendapat suplementasi seng.

Keseluruhan penelitian kami dilakukan dalam waktu enam bulan. Karena rentang waktu yang relatif lama, banyak faktor lain yang tidak bisa dikontrol dalam penelitian, seperti perubahan musim, diet, penyakit yang dapat mengganggu imunitas tubuh, serta higiene dan sanitasi lingkungan. Selain itu, adanya drop out juga tidak dapat dihindarkan. Untuk itu, diperlukan suatu Randomized clinical trial (RCT) untuk menilai efektifitas dari suplementasi seng dan vitamin A terhadap kejadian ISPA dan diare lebih lanjut.

\section{Kesimpulan}

Terdapat pengaruh suplementasi seng dan vitamin A terhadap penurunan angka kejadian ISPA dan diare pada anak. Akan tetapi, diperlukan suatu Randomized clinical trial (RCT) untuk menilai efektifitas dari suplementasi seng dan vitamin A terhadap kejadian ISPA dan diare lebih lanjut. Dengan demikian, hasil yang diperoleh dapat menjadi landasan yang lebih kuat untuk memulai program suplementasi seng bersamaan dengan program suplementasi vitamin A yang selama ini telah rutin dilakukan oleh pemerintah.

\section{Daftar pustaka}

1. Wantania JM, Naning R, Wahani A. Infeksi respiratori akut. Dalam: Rahajoe NN, Supriyatno B, Setyanto DB, penyunting. Buku ajar respirologi. Edisi 1. Jakarta: BPIDAI;2008.h.268-77.

2. Barness LA. Vitamin A nutrition and nutrition disorders. Dalam: Behrman RE ,penyunting. Nelson textbook of Pediatrics. Philadelphia London Toronto: WB Saunders Co; 1991.h.170-2.

3. Kementrian Kesehatan Republik Indonesia. Kerangka acuan persiapan survei kurang vitamin $\mathrm{A}$, anemia, dan seng ( $\mathrm{Zn})$. Puslitbang Gizi KemKes RI. Didapat dari: http://www.gizinet.com.

4. Rahman MM, Wahed MA, Fuchs GJ, Baqui AH, Alvarez JO. Synergistic effect of seng and vitamin A on the biochemical indexes of vitamin A nutrition in children. Am J Clin Nutr 2002;75:92-8.

5. Christian P, Keith PW Jr. Interaction between zinc and vitamin A: an update. Am J Clin Nutr 1998;68suppl:435s-41s.

6. Long KZ, Montoya Y, Hertzmark E, Santos JI, Rosado JL. A double-blind, randomized, clinical trial of the effect of vitamin A and zinc supplementation on diarrheal disease and respiratory track infection in children in Mexico City, Mexico. Am J Clin Nutr 2006;83:693700.

7. Fedriansyah. Hubungan status seng dan vitamin A dengan kejadian ISPA dan diare pada anak. Tesis/ Disertasi Palembang: Program Pendidikan Dokter Spesialis Ilmu Kesehatan Anak FK Universitas Sriwijaya/ RS. Moh. Hoesin, 2010.

8. Chang AB, Toezillo PJ, Boyce NC, White AV, Stewart PM. Zinc and vitamin A supplementation in Indigenous Australian children hospitalized wiyh lower respiratory tract infection: a randomized controlled trial. MJA 1984;184:107-11.

9. Sazawal S, Black RE, Jalla S, Mazumdar S. Zinc supplementation reduces the insidence of acute lower respiratory infections in infants and preschool children: a double blind controlled trial.Pediatrics 1998;102:1-5.

10. Smith JE, Brown ED, Smith JC jr. The effects of zinc deficiency on the metabolism of retinol binding protein in the rat. J Lab Clin Med 1974;84:692-7.

11. Brown ED, Smith JC, Chan W. Vitamin A metabolism during the repletion of zinc deficient rats. J Nut 1976;106:563-8.

12. Carney SM, Underwood BA, Loerch JD. Effects of zinc and vitamin A deficient diets on the hepatic mobilization and urinary excretion of vitamin A in rats. J Nutr 1976;106:1773-81.

13. Duncan JR, Hurley LS. An interaction between zinc and vitamin $A$ in pregnant and fetal rats. J Nutr 1978;108:1431-8.

14. Bhandari N, Bahl R, Taneja Sl. Effect of routine zinc supplementation on pneumonia in children aged 6 months to 3 years: randomised controlled trial in an urban slum. BMJ 2002;324:1358

15. Sempertequi F, Estrella B, Camaniero V. The beneficial effects of weekly low-dose vitamin A supplementation 
on acute lower respiratory infections and diarrhea in Ecuadorian children. Pediatrics 1999;104:e1.

16. Ruel M, Rivera JA, Santizo MD, Lonnerdal B, Brown $\mathrm{KH}$. Impact of zinc supplementation on morbidity from diarrhea and respiratory infections among rural Guatemalan children. Pediatrics 1997;99:808-13.

17. Aggarwal R, Sentz J, Miller MA. Role of zinc administration in prevention of childhood diarrhea and respiratory illnesses: a meta-analysis. Pediatrics 2006:3481:1120-30.

18. Rosmiati H, Wardhini BP. Vitamin A. Dalam Farmakologi dan terapi. Edisi 3. FK. Universitas Indonesia;1987. h. 657-60.

19. Pujiadi S. Vitamin A. Dalam: Ilmu gizi kinis pada anak. Edisi 4. Jakarta: Balai Penerbit FKUI; 2000.h.158-67.

20. Wapnir RA. Zinc deficiency, malnutrition and the gastrointestinal tract. J Nutr 2000;130:1389S-92S. 